\section{Aubert: 'A feisty Frenchwoman ... with a deep, audacious faith'}

A talk given by Sister Catherine Hannan, Leader of the Congregation of the Sisters of Compassion, at the launch of Jessie Munro's The Story of Suzanne Aubert (Auckland University Press/Bridget Williams Books), 6 November 1996.

This book, written in part during prolonged research at the Stout Research Centre, went on to win a number of awards in the 1997 Montana Book Awards, including Book of the Year.

$\mathrm{T}$ EN YEARS AGO we demolished the Home of Com passion at Island Bay - the Hospital and Children's Home built by Suzanne Aubert. Eight years earlier it had been declared a moderate earthquake risk and we had the option to strengthen or demolish and rebuild. Prayer, discussion and wrestling with the implications of the alternatives led to the decision to start anew - not an easy one for despite its many structural flaws we loved the building for it was a very tangible link with Suzanne Aubert who founded our Congregation. At immense personal cost she had built it - it was an Island Bay landmark with its grey bulk, squat below the hills as one travelled down Adelaide Road from Newtown into Berhampore and it was the scene of where so many of us had studied and trained. It was a precious link with our history - but there could be no turning back. The new building was erected, sisters and patients moved, and the demolition crew moved on to the site.

The demolition firm was led by a Scot, and a Mãori manned the bulldozer - both cultures sensitive to the intangible and that which is beyond. One morning a sister, pointing to a section of the building, commented to the Scot that they were approaching the room where Norman Kirk had died. 'Whatever you do,' he said, 'don't tell the men. Already they are aware they are demolishing a building very dear to many people who are actually on site watching them. They are aware that there is a spirit about this place. If you add anything more I don't think they could continue'.

I know that in writing this story of Suzanne Aubert, Jessie Munro was taking on much, much more. The former was a building. Jessie, however, was writing about a life, and not just someone from the past, but something which was very much alive - being lived by close on 120 women - dynamic, vigorous, some with memories of Suzanne, all with inherited stories (not always in accord). Naturally around such a figure there had arisen legends and some of these had become exaggerated, some wide of the truth.

Early in the project when asked, 'What if something is found you don't like?'. I had stated easily, perhaps too easily, 'I'm sure Suzanne Aubert is big enough to take the truth'. Later I wasn't sure if I was. For instance, Father Soulas' severe treatment of the women at Jerusalem when Suzanne had moved to Wellington, which caused my concern as to how appropriate was the publication of these essentially private happenings. But Jessie was aware of all this and most sensitive to it and on occasion caught in the dilemma between sensitivity to the living and the pursuit of historical and academic verity. And we all learnt in the process that the truth has within it the source of its own healing.

Through a variety of circumstances Jessie was the keynote speaker at an Assembly of all Sisters of Compassion when we came together in 1992 for our Centenary. Jessie spoke about Suzanne Aubert from her viewpoint as woman and teacher, a fifth generation New Zealander, mother of two daughters, from a Presbyterian background - and as such she wasn't burdened with baggage from the past or from Catholic piety - she had the facility to look with new and fresh eyes.

We listened with pleasure. Even our authority on Suzanne Aubert, Sister Philippine, considered that it was the most accurate interpretation she'd heard. Sister Philippine herself was a formidable woman. After many years teaching Māori youth in schools at Jerusalem and Ranana on the Whanganui River, as well as being fully immersed in the life of the Community epitomised by her riding on horseback to visit outlying families, her qualities of
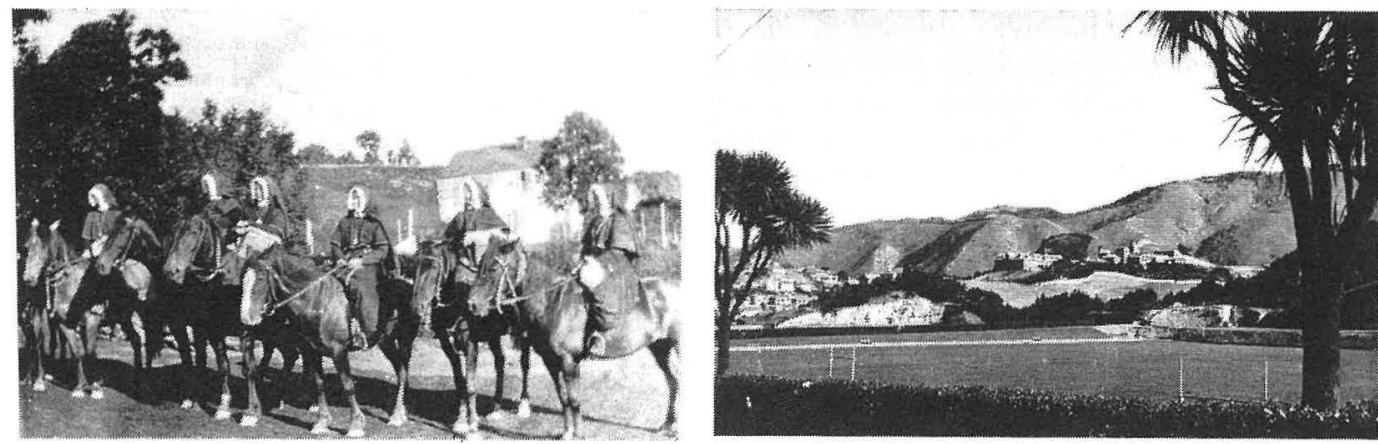


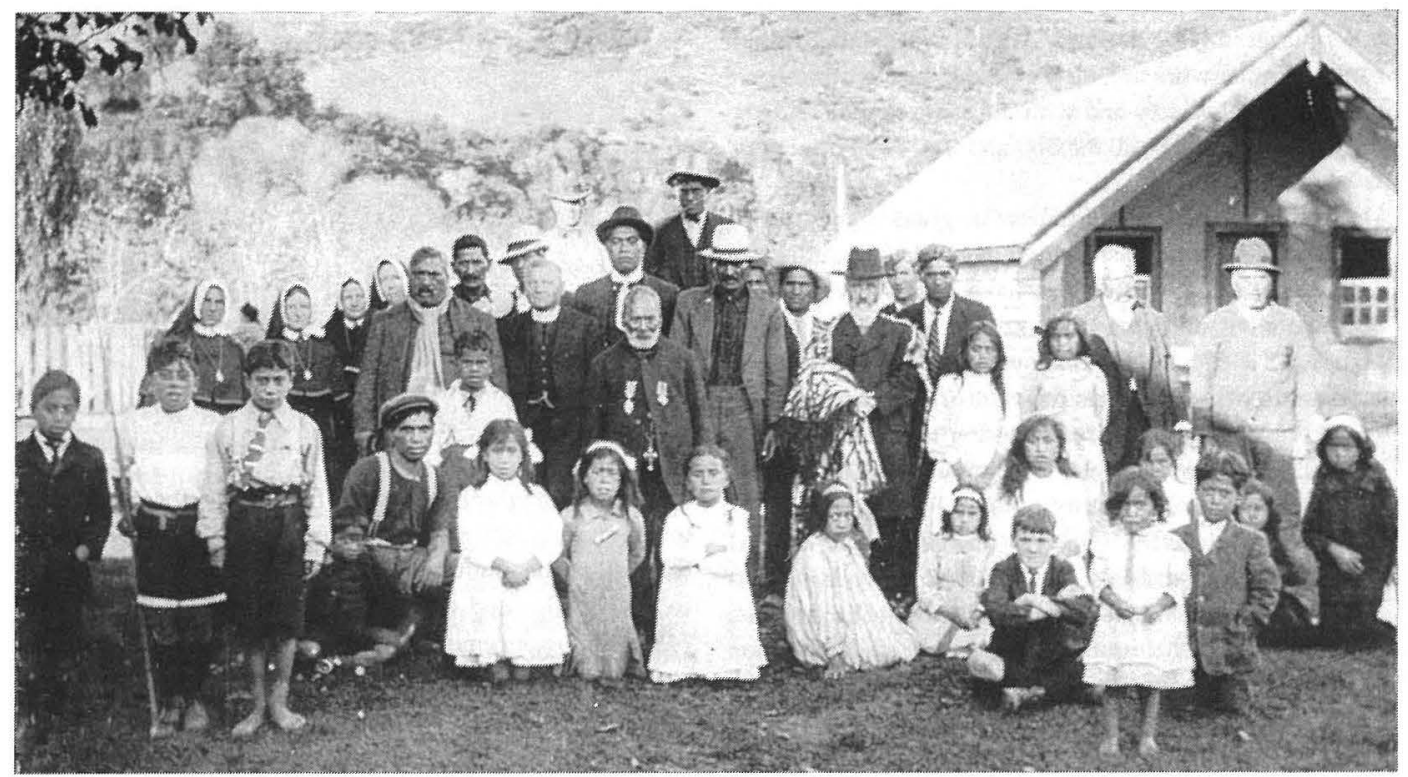

intelligence and energy led her to being chosen to lead the Congregation during the 1970s. My only regret is that Sister Philippine, Ruth Ross and Joan Akapita (who are all included in the book's dedication) are not with us today. How they would rejoice finally to see a definitive authentically researched work. And such a work.

Suzanne Aubert emerges as a strong feisty French woman: shrewd, intelligent, determined, lively. This is no plaster saint but a very human woman with the living deep audacious faith we know was hers with her unequivocal concern for the most needy of her time. Jessie, you have captured her in print so movingly that in reading it, frequently I found myself in tears. You have enabled us to see the big picture of Suzanne's personality and life with greater clarity. We had known most of the stories and anecdotes related in the book, but by placing them in

Opposite left: Sisters of Compassion returning from cherry picking at the farm at Jerusalem, Whanganui River. The original house where the plants for the medicines were dried and processed is in the background. Probably 1880s-1900s. Sisters of Compassion Archives, Island Bay.

Opposite right: Our Lady's Home of Compassion on the hills above Island Bay. Sisters of Compassion, Archive, Island Bay.

Above: Celebration of confirmation of young people, Ngāti Hau pā at Hiruharama ('the bottom $p \bar{a}^{\prime}$ ). Werahiko (catechist, wearing medals and cross), Rure Te Manihera Keremeneta (catechist, wearing white Panama hat), flanked by Father Julien Maillard (left), Bishop O'Shea (right, holding cloak), Sister Damien, Sister Veronica. 1890s.

Sisters of Compassion Archives, Island Bay. Figures identified by Sister Bernadette Mary Wrack. the ongoing sweep of her life and set in the social history of the time, seemingly isolated incidents take on a more profound significance.

This is a Wellington book - printed by Wellington printers, published by a Wellington publisher, Bridget Williams Books, now with Auckland University Press. We have valued the connection with you Bridget, and it has been great to work with you. It has been quite mindblowing learning something of the complexities involved in bringing a book to birth. And another Wellingtonian, despite her Auckland beginnings, who has been vital to the whole project is our Archivist, Sister Bernadette Mary Wrack. Her role has been much more encompassing than merely an assistant to Jessie.

The book begins and finishes at Hiruharama on the Whanganui River. And this is so right. It is where we began and where increasingly we now return. The place is important, but more so are the people. This is the story of Suzanne Aubert, but it could not be written without the people of the River, Ngāti Hau and Ngāti Ruaka. It is our story and your story. And Pat, Bernard, Nohi, Barbara, May, Katarina, Therese and Eileen, I am honoured to acknowledge your presence here today. Kia ora koutou.

This is the introduction you gave the book:

Standing on the banks of the flowing Whanganui River,

I can hear the trickling streams flowing towards the

River and the sweet call of the shining cuckoo, and my gaze goes out to a mass of people gathering

$$
\begin{aligned}
& \text {... tuparara te maru o te tangata } \\
& \text { that is you ... it is also us. }
\end{aligned}
$$

My final tribute is to the women who have kept her story going. The Sisters here today and all the others you represent who are unable to be here with us but are in 
other places in New Zealand, Australia, Fiji and Tonga, continuing her work among the needy, the sick, those on the margins of society and with the same single-minded purpose: 'We must be all for God and God must be all for us'.

So often we have debated with great diversity of opinion, what would she do today? How would she meet today's challenges? You have kept the vision of Suzanne alive, allowing it to endure through all kinds of obstacles. More than that: you have enabled it to blossom in new ways, into new cultures, in new times, you have 'depthed' her spirit. Her vision has become our vision. Without you the story would be history but it is - her story and our story.

Jessie completes the Epilogue: 'Bridging gaps was what Suzanne Aubert did best, and with an inviting confidence she directed those around her to do just the same'. She still does.

Throw a plant across the stream for us to cross to the other side: Kahupapangia te awa ki te rakau kia whiti tatou ki tera taha.

\section{(1) BOOK REVIEW}

\section{Elegance, mystery, autumnal sadness ...}

\section{The Opawa Affair}

\section{Edmund Bohan, Hazard Press, 1996}

\section{Reviewed by Nelson Wattie}

$\mathrm{I}^{\mathrm{N}}$

N THE ROBERT MCDOUGALL GALLERY in Christchurch there is a very striking and mysterious painting by G.D.Leslie called The Wizard's Garden. At the side of a moat in a well-trimmed garden stands an elegant shapely figure in a red, very impractical gown. She holds herself proudly - like a singer. Her eyes contrive to be both hauntingly sad and slightly surprised at the same time, while her small mouth suggests seriousness of purpose. Through an arched gateway in a high containing wall comes a dark figure in broad-rimmed hat and long robe, barely more than a silhouette, and again ambiguous: either threatening or friendly, depending on how your eyes are trained.

This painting graces the cover of Edmund Bohan's 19th-century mystery novel - a nice piece of book design - and suggests much of what is inside: elegance, mystery, autumnal sadness, careful design and a pre-Raphaelite sensuality. Although short, it is a book of several dimensions.

There is the Christchurch dimension: it is taken for granted that class distinctions divide this society almost as cleanly as Edward Gibbon Wakefield would have wanted, and that the top layer is an almost unapproach-

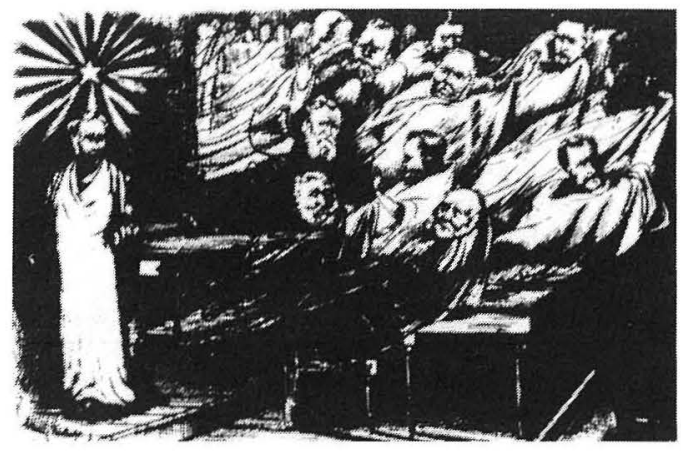

able, effete anglophile group, frustrating the Irish and lower-class investigator by setting up barriers as high as the wall in the painting. This is a leisured, sophisticated, relatively educated world with a seething under-surface of servants, policemen and prostitutes. And at its centre a medievalising cathedral is being constructed.

'Have a care, my good fellow! Mr Allen is a gentleman of the most exquisite breeding and, I believe, connected to the English nobility. Perhaps you are not aware of that fact?'.

'I'm aware that I'm investigating a murder, Sir. I need to know anything that might be relevant to that investigation'.

'Then do not let me hear you impugning the integrity of people of the Allen's rank, Sergeant O'Rorke!'.

Clearly, there is an Irish dimension, too. The most surprising people knew each other on the emerald isle before finding themselves stranded on the mainland. The victim and the policeman, for example; and the policeman and an Italian opera singer known to most as Tomaso Briani and to a few as Thomas O'Brien. The class distinctions have a strong national undertone and barriers can be breached in part by the solidarity of the Irish against the rest of the world.

There is the historical dimension, unsur-prisingly in one of the country's finest historical biographers. Here Bohan's erudition is worn lightly, but one feels secure in following his narrator through the atmosphere of time and place. Historical figures fit easily beside the fictitious ones and are treated as people with weaknesses rather than respected as icons. This is especially true of George Grey whose efforts to win an election emerge from the story here and there, but whose liking for the ladies is even more strongly featured. Bohan is, I believe, to write a biography of George Grey and again one can feel secure with this image, limited and briefly glimpsed though it is. But such historical features - they include Julius von Haast, laden with learning - are not permitted to take over or

Above: Sir George Grey's efforts to win the 1879 general election were depicted in New Zealand Punch. Sir George 'in a halo of light' is being deserted by his followers, the 'Auckland rats'. Canterbury Public Library. 